\title{
Epicotyl length in seedlings of soybean cultivars subjected to reduced inter-row spacing
}

\author{
Willian Daniel dos Reis Gontijo ${ }^{1}{ }^{\infty}$, Pedro Henrique Santos Sousa ${ }^{1}{ }^{(0}$, Éder Matsuo ${ }^{2, *}{ }^{(}$, Jorge \\ Cunha Resende ${ }^{1}\left(\mathbb{D}\right.$, Paulo Henrique Frois Correa Barros ${ }^{1}\left(\mathbb{C}\right.$ and Gustavo Lourenço Bomtempo ${ }^{1}[$
}

${ }^{1}$ Agrarian Sciences Institute, Federal University of Viçosa - Rio Paranaíba Campus, Rio Paranaíba, MG, Brazil. ${ }^{2}$ Technological and Exact Sciences Institute, Federal University of Viçosa - Rio Paranaíba Campus, Biostatistics Laboratory, Highway MG 230, Km 7, PO Box 22, CEP 38810-000, Rio Paranaiba, MG, Brazil. *Corresponding author, Email: edermatsuo@ufv.br

\begin{abstract}
The objective was to evaluate the epicotyl length of seedlings of soybean cultivars in the field, submitted to plant densification by reducing the inter-row spacing. Two field experiments were conducted in Rio Paranaíba in the state of Minas Gerais and the effect of reduced spacing $(20 \mathrm{~cm}, 30 \mathrm{~cm}, 40 \mathrm{~cm}$ and $50 \mathrm{~cm}$ between rows) was evaluated. The assessment of the epicotyl length was done by using a millimeter ruler when the plants reached the V2 development stage. The experiments were conducted in a randomized block design with four repetitions. In experiment 1, the BRSMG752S cultivar was submitted to four interrow spacings and no differences were found among them. In experiment 2 , the simple factorial scheme $4 x$ 3 was considered, with 4 spacings and 3 cultivars, to analyze the effect of the interaction between cultivars (96R10, 97R50 and 98Y21) and spacing (20,30, 40 and $50 \mathrm{~cm}$ between rows). The results of experiment 2 indicated that there was no significant effect for spacing and that the cultivars presented statistically different averages. Thus, it can be concluded that the epicotyl length of soybean seedlings, grown in the field in Rio Paranaíba in the state of Minas Gerais and evaluated at the V2 stage of development, was not influenced by the distance between the sowing lines and that the cultivar 96R10 showed the highest and 98Y21 the lowest mean epicotyl length of soybean seedlings, grown in the field in Rio Paranaíba in the state of Minas Gerais and evaluated at the V2 stage of development.
\end{abstract}

Keywords: Glycine max, cultivation, densification, interaction, shading, distinctiveness.

\section{INTRODUCTION}

The soybean (Glycine max (L.) Merr.) crop has assumed a role of such importance in the world and Brazilian agricultural scenario that its economy started to influence the development of research, technologies, agribusinesses, production chain and infrastructure and the development of Brazilian agriculture is closely related to the evolution and expansion of soybeans in the country (Tancredi, Silva, Matsuo, \& Sediyama, 2020).

Several factors were responsible for the growing increase in soybean production in Brazil, among them the evolution of the crop via genetic improvement (Tancredi et al., 2020). In the 2020/2021 harvest, Brazilian soybean production is estimated at 135.13 million tons on 38.5 million hectares in the 2020/21 harvest, resulting an average productivity of $3509.87 \mathrm{~kg} \mathrm{ha}^{-1}$ (Companhia Nacional de Abastecimento [CONAB], 2021).

The genetic improvement of soybean through different institutions of research, education and extension has contributed to the direct increase in the production and grain yields in Brazil by launching new cultivars and recommending them for different growing environments. According to Vasconcelos-Neto, Borém and Portugal (2005) the distinction of cultivars is performed by a minimum margin of specific descriptors and, according to Nogueira et al. (2008), these descriptors are still insufficient to distinguish cultivars, which makes evident the need to expand the list of descriptors that were used. Among the various characters, epicotyl length has stood out as a potential additional descriptor for soybean culture (Silva et al., 2016; Hanyu, Ferreira, Cecon, \& Matsuo, 2020).

In the context of epicotyl length, the evaluation in the field is still poorly studied and more studies are needed to assess the effect of reducing row spacing (with a consequent increase in plant density per square meter). The effect of increasing plant density on among several characters, plant height has been 
evaluated; these report that plant densification per unit area results in increased plant height at harvest (Knebel, Guimarães, Andreotti, \& Stangarlin, 2008; Carmo, Rocha, Simon, Silva, \& Braz, 2018). This is due to the competition for light, caused by the greater shading between plants (Moore, 1991). However, the evaluation of epicotyl length has been performed in the early stages of the crop, in V2 or V3 (Camargos, Campos, Alves, Ferreira, \& Matsuo, 2019; Hanyu et al., 2020) and it is expected that at this stage the total shading of the inter-rows has not yet occurred, even with reduced spacing and higher plant density per area. Given this, the objective was to evaluate the epicotyl length of seedlings of different soybean cultivars, in the field, submitted to plant densification by reducing the inter-row spacing.

\section{MATERIALS AND METHODS}

The experiments were conducted in the field at the Federal University of Viçosa - Rio Paranaíba Campus (19 $11^{\circ}$ ' 39" S; 46 $14^{\prime} 37^{\prime \prime} \mathrm{W}, 1133 \mathrm{~m}$ of altitude), whose soil is classified as Red-Yellow Latosol with a very clayey texture (Empresa Brasileira de Pesquisa Agropecuária [EMBRAPA], 2013). The conduction of the experiment, from the preparation of the area until the time of the evaluations, was performed as recommended in Sediyama (2009).

Experiment 1 was installed in February 2019 using seeds of the BRSMG752S cultivar. The average temperature was $24.1^{\circ} \mathrm{C}$ (minimum temperature $17.4^{\circ} \mathrm{C}$ and maximum temperature $30.7^{\circ} \mathrm{C}$ ). When the plants reached the VC development stage (Fehr \& Caviness, 1977), thinning was carried out in order to maintain 16 plants per linear meter, for four row spacings (Treatment 1: 20 centimeters between rows; Treatment 2: $30 \mathrm{~cm}$ between rows; Treatment 3: 40 centimeters between rows; and Treatment 4: 50 centimeters between rows), according to Figure 1. In this situation the spatial arrangement of the plants was altered, since the reduction in inter-row spacing was implemented and the number of plants per linear meter was maintained.

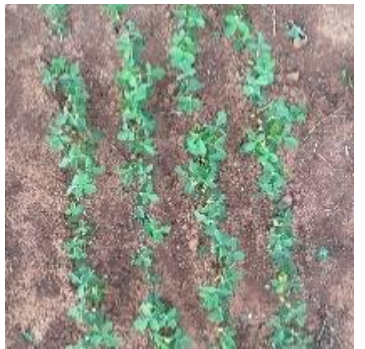

(A)

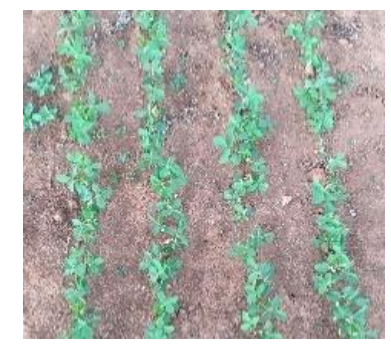

(B)

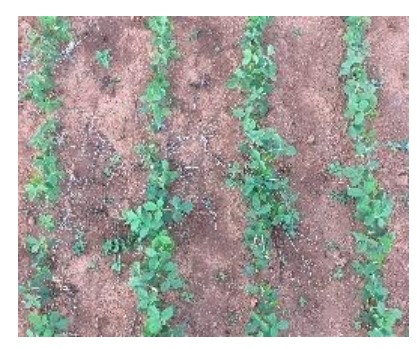

(C)

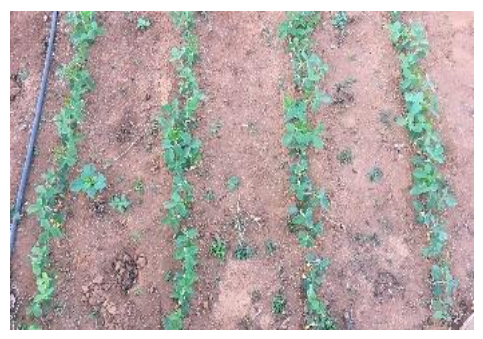

(D)

Figure 1. Illustrative images of row spacing, being (A): Treatment $1-20$ centimeters between rows; (B): Treatment 2 - 30 centimeters between rows; (C): Treatment 3 - 40 centimeters between rows; and (D): Treatment 4 - 50 centimeters between rows. Photo taken in experiment 1 when the plants reached the V2 stage of development (Fehr \& Caviness, 1977). Photos taken by Éder Matsuo.

The randomized block design was used, with four blocks and information within the plot (16 plants per experimental unit, randomly drawn within the useful area). Each plot was composed of four rows, $200 \mathrm{~cm}$ long; and the usable area was composed of two central rows, disregarding $50 \mathrm{~cm}$ at the two edges. For statistical analysis, the variance analysis was performed and the coefficients of variation (in \%) were estimated.

Experiment 2 was installed in October 2019 using seeds from the cultivars 96R10, 97R50 and 98Y21. The average temperature was $25.6^{\circ} \mathrm{C}$ (minimum temperature $21.2^{\circ} \mathrm{C}$ and maximum temperature $28.1^{\circ} \mathrm{C}$ ). At the moment that the plants reached the VC development stage (Fehr \& Caviness, 1977), thinning was carried out in order to maintain 18 plants per linear meter for Cultivar 96R10, 16 plants per linear meter for Cultivar 97R50, and 10 plants per linear meter for Cultivar 98Y21 for the same inter-row spacings considered in Experiment 1 . The randomized block design was performed with four repetitions, in a $4 \times 3$ simple factorial scheme, with four spacings and three cultivars. Each experimental unit was composed of the average of 16 plants from the useful area of the plot. Each plot was composed of four rows, $200 \mathrm{~cm}$ long; and the usable area was composed of two central rows, disregarding $50 \mathrm{~cm}$ at both edges.

The epicotyl length measurements (distance between the node where the unifolioliate leaves are inserted and the node where the first trifoliolate leaf is inserted), in both experiments, were performed when the 
plants reached the V2 development stage (Fehr \& Caviness, 1977), using a millimeter ruler with measurements in centimeters.

The R Program (R Core Team, 2020) was used, considering $1 \%$ or $5 \%$ probability for significance level, in the analysis of variances by the $\mathrm{F}$ test and experimental coefficient of variation (CVe) and Tukey's test $(\alpha=5 \%)$. To estimate the genetic parameters (genotypic coefficient of variation, the $\mathrm{CVg} / \mathrm{CVe}$ ratio and the genotypic coefficient of determination $\left(H^{2}\right)$, the Genes Program (Cruz, 2013) was used.

\section{RESULTS AND DISCUSSION}

No significant effect was identified for the source of variation spacing at $5 \%$ level of significance by the ANOVA F test and with a coefficient of variation in the magnitude of $7.96 \%$ (Table 1). This indicates that the inter-row spacing did not influence the development of epicotyl length of soybean seedlings of cultivar BRSMG752S evaluated at the V2 developmental stage.

Table 1. Summary of variance analysis for Epicotyl Length, evaluated in centimeters at the V2 development stage, in seedlings of the BRSMG752S cultivar sown at four inter-row spacings in the field of Rio Paranaíba, Minas Gerais, 2019.

\begin{tabular}{lcc}
\hline \multicolumn{1}{c}{ Variation sources } & Degrees of freedom & Average squares $^{1}$ \\
\hline Blocks & 3 & 1.6564 \\
Spacing & 3 & $3.1486^{\mathrm{ns}}$ \\
Residue (between) & 9 & 3.2597 \\
Residue (inside) & 560 & 0.4668 \\
\hline General average $($ in cm) & & 3.77 \\
Coefficient of Variation (\%) & & 7.96 \\
\hline $1 / * *$ and ns. Significant at $1 \%$ and non-significant, respetively, by the F Test.
\end{tabular}

1/**and ns: Significant at $1 \%$ and non-significant, respectively, by the $\mathrm{F}$ Test.

The effect of the Spacing $x$ Cultivar interaction and the isolated factor spacing were not significant at 5\% significance by the ANOVA F test, with a coefficient of variation in the magnitude of $7.35 \%$. The effect of cultivar was significant (Table 2). This indicates that the averages of the cultivars were statistically different when subjected to the measurement of epicotyl length in seedlings evaluated at the V2 developmental stage, in field.

When analyzing the isolated effect of the cultivar, it was observed that 96R10 showed the highest average for epicotyl length, followed by $97 \mathrm{R} 50$ and $98 \mathrm{Y} 21$ (Table 3). This shows that there is a significant difference between cultivars when the epicotyl length is measured in soybean seedlings at the V2 development stage, in field.

The magnitudes of the coefficients of variation obtained in Experiment 1 and 2 were $7.96 \%$ and 7.35\%, respectively, and they corroborate with those obtained by Nogueira et al. (2008), Matsuo, Sediyama, Cruz, Oliveira and Cadore (2012a) and lower than those obtained by Silva et al. (2016), Chaves et al. (2017), Camargos et al. (2019) and Hanyu et al. (2020).

Several works in the literatures report that reducing the inter-row spacing associated with increasing the plant population density per area results in increased final plant height, namely plant height at harvest, as in Carmo et al. (2018) who reported that plant height was affected by the interaction of sowing season and inter-row spacing; and in Knebel et al. (2008) who observed the higher the plant population per square meter the higher the plant height was. This is because, according to Moore (1991) the increased competition for light due to the greater shading caused by adjacent plants in high density promotes greater plant height.

In the present study, epicotyl length was measured when the seedlings reached the V2 developmental stage and no severe shading in full sun was identified, namely, inter-row closure (total soil shading by plants 
in adjacent rows) at the four considered spacings. For the cultivar CD202 at the inter-row spacing of 22.5 $\mathrm{cm}$ the total inter-row closure occurred at V4 (29 days after emergence - DAE), while at the $67.5 \mathrm{~cm}$ spacing the total inter-row closure occurred only at the V12 stage (49 DAE) (Knebel et al., 2008) and, according to Gibbert et al. (2018) plant height was affected by variety but not by density (densities of 8, 10, 12 and 14 apt plants per linear meter, with spacing of 0.45 meters in the inter-row).

Table 2. Summary of variance analysis for Epicotyl Length, evaluated in centimeters at the V2 development stage, in seedlings of three soybean cultivars sown at four inter-row spacings in the field of Rio Paranaíba, Minas Gerais, 2019.

\begin{tabular}{lcc}
\multicolumn{1}{c}{ Variation sources } & Degrees of freedom & Average squares $^{\mathbf{1}}$ \\
\hline Blocks & 3 & 0.4380 \\
Spacing & 3 & $0.0485^{\mathrm{ns}}$ \\
Cultivars & 2 & $8.5017^{* *}$ \\
Spacing * Cultivars & 6 & $0.0662^{\mathrm{ns}}$ \\
Residue & 33 & 0.0772 \\
\hline General average $($ in cm) & & 3.78 \\
Experimental Coefficient of Variation (CVe) $(\%)$ & 7.35 \\
\hline Ratio CVg/CVe & & 2.61 \\
Coefficient of Genotypic Determination (H $\left.{ }^{2}\right)(\%)$ & 99.09 \\
\hline 1/** and ns: Significant at $1 \%$ and non-significant, respectively, by the F Test. &
\end{tabular}

Table 3. Averages of Epicotyl Length, in centimeters, measured in three soybean cultivars (96R10, $97 R 50$ and 98Y21) grown in the field of Rio Paranaíba, Minas Gerais, 2019.

\begin{tabular}{|c|c|}
\hline Cultivars & Epicotyl Length $_{(\text {in } \mathrm{cm})}{ }^{1}$ \\
\hline 96R10 & $4.54 \quad \mathrm{a}$ \\
\hline 97R50 & $3.72 \mathrm{~b}$ \\
\hline $98 Y 21$ & $3.09 \mathrm{c}$ \\
\hline
\end{tabular}

\footnotetext{
${ }^{1 /}$ Averages followed by the same lower-case letter in the column do not differ at $5 \%$ probability using the Tukey test.
}

Concerning the fact of having identified significant difference between cultivars regarding the epicotyl length of soybean seedlings evaluated at the V2 development stage, the present work corroborates with those of Matsuo et al. (2012a), Matsuo, Sediyama, Cruz and Oliveira (2012b), Silva et al. (2016), Chaves et al. (2017), Alves et al. (2019), Camargos et al. (2019) and Hanyu et al. (2020). The observed significance indicates that the soybean genotypes show differences among themselves, which enables successful selection of promising materials (Matsuo et al., 2012b). This difference is mainly influenced by genetic components in phenotypic expression, by the fact that the magnitude of the estimate of $\mathrm{H}^{2}$ (Coefficient of genotypic determination) was identified as greater than 98\% (Matsuo et al., 2012a). Furthermore, according to Vieira, Pinho, Carvalho, \& Silva, (2009), morphological characteristics evaluated in the seedling phase and those evaluated in the seeds should be preferred, because they allow to obtain a quick result, with no need to wait for adult plants.

The magnitude of the $\mathrm{CVg} / \mathrm{CV}$ e ratio was 2.61. This parameter, the $\mathrm{CVg} / \mathrm{CV}$ e ratio is an extremely relevant information for the plant breeder, because when it reaches a value of 1.0 or higher it indicates a very favorable situation for selection (Santos, Spehar, Pereira, Capone, \& Barros, 2019). And the magnitude of the genotypic determination coefficient $\left(\mathrm{H}^{2}\right)$ was equal to $99.09 \%$. According to Cruz (2005) $\mathrm{H}^{2}$ is a measure 
analogous to heritability and it expresses the phenotypic variance due to genetic variability among treatment averages, so that, high estimates of $\mathrm{H}^{2}$ indicate that most of the variation among genotype means is genetic in nature (Vencovsky, 1987).

The results, from both experiments, indicated that the distance between sowing rows, namely the spacing between rows did not influence (positively or negatively) the epicotyl length of soybean seedlings evaluated in the field at the V2 developmental stage. These are results from two experiments, in which the total of four cultivars were evaluated in two agricultural years, late harvest year 2018/2019 and early 2019/2020, which could not be compared statistically. The present study is innovative and contributes to the beginning of the understanding of the behavior of this variable in the field. Further studies regarding the evaluation of this variable in other cultivars and in different environments are necessary for a better understanding of the behavior of this variable as a function of the spacing between the sowing lines (sowing density) and, also, the interaction of cultivars and environments (sowing locations).

\section{CONCLUSIONS}

The epicotyl length of soybean seedlings, grown in the field in Rio Paranaíba - Minas Gerais and evaluated at the V2 development stage, was not influenced by the distance between the sowing lines $(20,30,40$ and $50 \mathrm{~cm}$ between lines).

The cultivar 96R10 had the highest and 98Y21 the lowest average regarding epicotyl length of soybean seedlings, grown in the field in Rio Paranaíba - Minas Gerais and evaluated at the V2 stage of development.

\section{REFERENCES}

Alves, G. F., Nogueira, J. P. G., Machado-Junior, R., Ferreira, S. C., Nascimento, M., \& Matsuo E. (2019). Stability of the hypocotyl length of soybean cultivars using neural networks and traditional methods. Ciência Rural, 49 (3), e20180300. https://doi.org/10.1590/0103-8478cr20180300

Camargos, T., Campos, N, Alves, G. F., Ferreira, S. C., \& Matsuo, E. (2019). The effect of soil volume, plant density and sowing depth on soybean seedlings characters. Agronomy Science and Biotechnology, 5 (2), 47. doi: https://doi.org/10.33158/ASB.2019v5i2p47

Carmo, E. L., Rocha, A. G. C., Simon, G. A., Silva, A. G., \& Braz, G. B. P. (2018). Adensamento de plantas e épocas de cultivo de soja em condições de cerrado. Colloquium Agrariae, 14 (2), 01-12. doi: https://doi.org/10.5747/ca.2018.v14.n2.a201

Chaves, M. V. A., Silva, N. S., Silva, R. H. O., Jorge, G. L., Silveira, I. C., Medeiros, L. A., Hamawaki, C. D. L., Medeiros, L. A., Hamawaki, R. L., Hamawaki, O. T., \& Nogueira, A. P. O. (2017). Genotype x environment interaction and stability of soybean cultivars for vegetative-stage characters. Genetics and Molecular Research, 16 (3), 1-10. doi: https://doi.org/10.4238/gmr16039795

CONAB - Companhia Nacional de Abastecimento. (2021) Acompanhamento da safra brasileira de grãos. Safra 2020/2021 - sexto levantamento. http://www.conab.gov.br

Cruz, C. D. (2013). GENES: a software package for analysis in experimental statistics and quantitative genetics. Acta Scientiarum. Agronomy, 35(3), 271-276. https://doi.org/10.4025/actasciagron.v35i3.21251

Cruz, C. D. (2005) Princípios de genética quantitativa. Viçosa, MG: UFV.

EMBRAPA - Empresa Brasileira de Pesquisa Agropecuária. (2013). Sistema brasileiro de classificação de solos. (3 $3^{\text {rd }}$ ed.). Brasília, DF.

Fehr, W. R., \& Caviness, C. E. (1977). Stage of soybean development (Special Report). Ames: lowa State University. Retrieved from http://lib.dr.iastate.edu/specialreports/87 

agronômicas de dois cultivares de soja sob diferentes densidades de semeadura. Revista Cultivando o Saber, 9 (3), 61 a 68.

Hanyu, J., Ferreira, S. C., Cecon., P. R., \& Matsuo, E. (2020). Genetic parameters estimate and characters analysis in phenotypic phase of soybean during two evaluation periods. Agronomy Science and Biotechnology, 6, 1-12. doi: https://doi.org/10.33158/ASB.r104.v6.2020

Knebel, J. L., Guimarães, V. F., Andreotti, M., \& Stangarlin, J. R. (2008). Influência do espaçamento e população de plantas sobre doenças de final de ciclo e oídio e caracteres agronômicos em soja. Acta Scientiarum. Agronomy. 28 (3), 385-392. doi: https://doi.org/10.4025/actasciagron.v28i3.962.

Matsuo, E., Sediyama, T., Cruz, C. D., \& Oliveira, R. C. T. (2012b). Análise da repetibilidade em alguns descritores morfológicos para soja. Ciência Rural, 42 (2), 189-196. doi: https://doi.org/10.1590/S010384782012000200001

Matsuo, E., Sediyama, T., Cruz, C. D., Oliveira, R. C. T., \& Cadore, L. R. (2012a). Estimates of the genetic parameters, optimum sample size and conversion of quantitative data in multiple categories for soybean genotypes. Acta Scientiarum Agronomy, 34 (3), 265-273. doi: https://doi.org/10.1590/S180786212012000300006

Moore, S. H. (1991) Uniformity of planting effect on soybean population parameters. Crop Science, 31 (4), 1049-1051. doi: https://doi.org/10.2135/cropsci1991.0011183X003100040041x

Nogueira, A. P. O., Sediyama, T., Cruz, C. D., Reis, M. S., Pereira, D. G., \& Jangarelli, M. (2008). Novas características para diferenciação de cultivares de soja pela análise discriminante. Ciência Rural, 38 (9), 2427-2433. doi: https://doi.org/10.1590/S0103-84782008005000025

R Core Team. (2020). R: A language and environment for statistical computing. Vienna, Austria: R Foundation for Statistical Computing. URL https://www.R-project.org/

Santos, E. R., Spehar, C. R., Pereira, P. R., Capone, A, \& Barros, H. B. (2019) Parâmetros genéticos e avaliação agronômica em progênies F2 de soja no Distrito Federal, Brasil. Revista Brasileira de Ciências Agrárias, v.14, n.1, e5625. doi: https://doi.org/10.5039/agraria.v14i1a5625

Sediyama, T. (2009). Tecnologias de produção e usos da soja. Londrina, PR: Editora Mecenas.

Silva, F. C. S., Sediyama, T., Silva, A. F., Bezerra, A. R. G., Rosa, D. P., Ferreira, L. V., \& Cruz, C. D. (2016). Identification of new descriptors for differentiation of soybean genotypes by Gower algorithm. African Journal of Agricultural Research, 11 (11), 961-966. doi: https://doi.org/10.5897/ajar2015.10158

Tancredi, F. D., Silva, F. C. S., Matsuo, E., \& Sediyama, T. (2020) Origem, distribuição geográfica e importância econômica. In Matsuo, E., Cruz, CD \& T Sediyama (Eds.) Aplicações de técnicas biométricas no melhoramento genético da soja (pp.13-24). Londrina-PR: Editora Mecenas.

Vasconcelos-Neto, M. O., Borém, A., \& Portugal, R. S. (2005) Lei de proteção de cultivares. In Borém, A. (Ed.) Melhoramento de espécies cultivadas (pp. 931-960). Viçosa, MG: Editora UFV.

Vencovsky, R. (1987) Herança quantitativa. In: Paterniani, E.; \& Viegas, G. P. (Ed.). Melhoramento e produção de milho. Campinas, SP: Editora Fundação Cargil, p. 135-214. 
Vieira, E. S. N., Pinho, E. V. R. V., Carvalho, M. G. G, \& Silva, P. A. (2009). Caracterização de cultivares de soja por descritores morfológicos e marcadores bioquímicos de proteínas e isoenzimas. Revista Brasileira de Sementes, 31 (1), 086-094. doi: https://doi.org/10.1590/S0101-31222009000100010

\section{Received: April 21, 2021.}

Accepted: May 5, 2021.

Published: May 24, 2021.

\section{English by: André Luis Miyagaki.}

